\title{
Identifikasi Permasalahan Pelayanan Izin Mendirikan Bangunan (IMB) di Kota Surabaya melalui Surabaya Single Window
}

\author{
Imroatul Azizah, Ardy Maulidy Navastara \\ Departemen Perencanaan Wilayah dan Kota, Fakultas Arsitektur Desain dan Perencanaan \\ Institut Teknologi Sepuluh Nopember (ITS) 60111 Indonesia \\ e-mail: ardy.navastara@urplan.its.ac.id
}

\begin{abstract}
Abstrak-Pelayanan Izin Mendirikan Bangunan (IMB) di Kota Surabaya dilakukan dengan mengakses Surabaya Single Window sehingga lebih transparan dan terintegrasi antar Satuan Kerja Perangkat Daerah. Adanya peran masyarakat yang sadar pentingnya Teknologi Informasi dan Komunikasi (TIK) yang tergabung Kelompok Informasi Masyarakat (KIM) dan petugas yang terlatih, tidak menjadikan seluruh bangunan di Kota Surabaya memiliki Izin Mendirikan Bangunan. Penelitian dilakukan dengan mengidentifikasikan kegiatan pelayanan menurut sistem, dan mengeksplorasi permasalahan pelayanan Izin Mendirikan Bangunan dengan batasan pelayanan melalui Unit Pelayanan Terpadu Satu Atap. Identifikasi kegiatan pelayanan menurut sistem menggunakan analisis deskriptif, sedangkan permasalahan pelayanan Izin Mendirikan Bangunan menggunakan analisis deskriptif kualitatif terhadap sample pemohon, serta analisis Isi terhadap Unit Pelayanan Terpadu Satu Atap dan Dinas Cipta Karya dan Tata Ruang Kota Surabaya. Penelitian ini menyimpulkan masyarakat Kota Surabaya belum sepenuhnya memahami pelayanan Izin Mendirikan Bangunan di Kota Surabaya khususnya detail klausul persyaratan, dan tahapan pelayanan serta adanya sistem eror dalam tahap pengunggahan data.
\end{abstract}

Kata Kunci-Izin Mendirikan Bangunan, Tahapan Pelaksanaan Izin Mendirikan Bangunan, Unit Pelayanan Terpadu Satu Atap, Dinas Cipta Karya dan Tata Ruang, Surabaya Single Window.

\section{PENDAHULUAN}

$\mathrm{P}$ EMBANGUNAN Kota Surabaya menuju Smart city ini telah dimulai dari pembenahan kinerja pemerintah melalui bantuan teknologi sebagai alat untuk penunjang kinerja pemerintah menjadi lebih baik, cepat, dan efisien. Dengan adanya sistem pemerintahan yang seperti itu, maka diharapkan pelayanan publik yang dilakukan oleh Pemerintah menjadi lebih optimal [1]. Surabaya Single Window (SSW) merupakan bentuk pelayanan pengurusan perizinan yang dimiliki Pemerintah Kota Surabaya yang terintegrasi dan juga dilakukan menggunakan sistem online. Sistem ini merupakan bentuk kerja sama antar Dinas Cipta Karya dan Tata Ruang dan beberapa SKPD terkait yang terhubung melalui System Informasi Management (SIM) yang dikoordinasi oleh Dinas Komunikasi dan Informatika.

Sebuah sistem merupakan kumpulan komponen dimana masing masing komponen memiliki fungsi yang saling berinteraksi dan saling bergantung serta memiliki satu kesatuan yang utuh dan saling bekerja sama untuk mencapai tujuan tertentu. Pada prinsipnya suatu sistem memiliki komponen input, proses, dan output [2]. Pemanfaatan Surabaya Single Window ini sudah dilaksanakan sejak tahun 2013 berdasarkan Peraturan Walikota Surabaya No. 28
Tahun 2013 tentang Tata Cara Pelayanan perizinan dan Non perizinan Secara Elektronik di Kota Surabaya. Salah satu bentuk perizinan yang dijalankan pada Surabaya Single Window adalah perizinan Izin Mendirikan Bangunan (IMB) sebagai pelayanan publik yang berperan dalam menjadikan tatanan kota menjadi lebih teratur dan bentuk kepastian hukum bagi masyarakat. Oleh karena itu pelaksanaan Izin Mendirikan Bangunan memiliki pengaruh penting dalam pengelolaan tata ruang kota. Berdasarkan Peraturan Pemerintah Republik Indonesia No 65 tahun 2005, Standar Pelayanan mengatur aspek input (pemasukan), proses, output (keluaran/hasil), dan atau outcome (manfaat).

Kegiatan input persyaratan dapat dilakukan secara online ataupun dilakukan secara manual di Unit Pelayanan Terpadu Satu Atap (UPTSA) Kota Surabaya kemudian proses dilakukan pada dinas dinas terkait perizinan, sedangkan pengambilan berkas perizinan dapat dilakukan di Unit Pelayanan Terpadu Satu Atap (UPTSA) Kota Surabaya [3]. Adanya penerapan pelayanan Izin Mendirikan Bangunan melalui sisitem online bagi Kota Surabaya sendiri merupakan salah satu bentuk perwujudan dari pemerintahan Smart City yang berprinsip Good Governance, sebagai langkah mengurangi praktik ruang gerak kecurangan petugas. Sejak awal peluncuran Sistem Pelayanan Surabaya Single Window tahun 2013 ini sendiri Pemerintah selalu berusaha meningkatkan pelayanan publik guna meningkatkan partisipasi masyarakat dalam melakukan perizinan melalui sistem Surabaya Single Windows.

Perkembangan teknologi dan informasi ini menjadikan masyarakat membutuhkan segala bentuk akses jaringan untuk memenuhi kebutuhan informasi. Upaya yang dilakukan masyarakat Surabaya diwujudkan dalam pembentukkan Kelompok Informasi Masyarakat (KIM) sebagai agen informasi. Kelompok Informasi Masyarakat adalah wujud masyarakat yang sadar informasi dan menjadi fasilitator untuk menjembatani kesenjangan komunikasi yang terjadi antara pemerintah dengan masyarakat atau sebaliknya. Kelompok Informasi Masyarakat hadir di Kecamatan dan hampir di setiap kelurahan di Kota Surabaya [4]. Disamping itu Pemerintah juga memiliki komitmen untuk mengembangkan Teknologi Informasi dan Komunikasi (TIK) untuk dunia pendidikan dan Kebudayaan. Selain bentuk dukungan Teknologi Informasi dan Komunikasi (TIK) terhadap masyarakat Kota Surabaya, Pemerintah Kota Surabaya juga tidak luput memberikan perhatian pada aparat pemerintah Kota Surabaya yakni dengan mengikutsertakan 3 perwakilannya pada pelatihan Teknologi Informasi dan Komunikasi terhadap pegawai Pemerintah Kota Surabaya di Malaysia pada tahun 2014. 
Faktanya, meskipun terjadi peningkatan warga yang melakukan perizinan Izin Mendirikan Bangunan pada setiap tahunnya, akan tetapi sampai saat ini masih ada bangunan di Kota Surabaya yang belum mempunyai Izin Mendirikan Bangunan. Berbagai upaya telah dilakukan Pemerintah Kota Surabaya untuk menarik masyarakat diantaranya mempersingkat waktu pengurusan, bantuan gambar bidang rumah khusus untuk rumah tinggal, dan tidak adanya denda. Oleh karena itu, diperlukan penelitian identifikasi permasalahan pelayanan Izin Mendirikan Bangunan di Kota Surabaya dengan akses Surabaya Single Window melalui Unit Pelayanan Terpadu Satu Atap guna menjadikan pelayanan Izin Mendirikan Bangunan di Kota Surabaya menjadi lebih baik dan menarik minat masyarakat.

\section{TINJAUAN PUSTAKA}

\section{A. Metode Pengumpulan Data}

Kegiatan pengumpulan data adalah rangkaian kegiatan yang dilakukan dalam rangka memperoleh data-data yang dibutuhkan sebagai data masukan yang akan dilakukan proses analisa sesuai tujuan penelitian. Secara keseluruhan, penelitian ini menggunakan metode pengumpulan data primer dan data sekunder. Pengumpulan data primer dilakukan dengan cara survey primer/secara langsung pada lokasi penelitian dengan cara penyebaran kuisioner, observasi dan wawancara di Unit Pelayanan Terpadu Satu Atap dan Dinas Cipta Karya dan Tata Ruang Kota Surabaya. Sedangkan pengumpulan data sekunder dilakukan dengan survei literatur terkait instansi terkait seperti Unit Pelayanan Terpadu Satu Atap Kota Surabaya dan Dinas Cipta Karya dan Tata Ruang serta Proses Pelayanan Izin Mendirikan Bangunan.

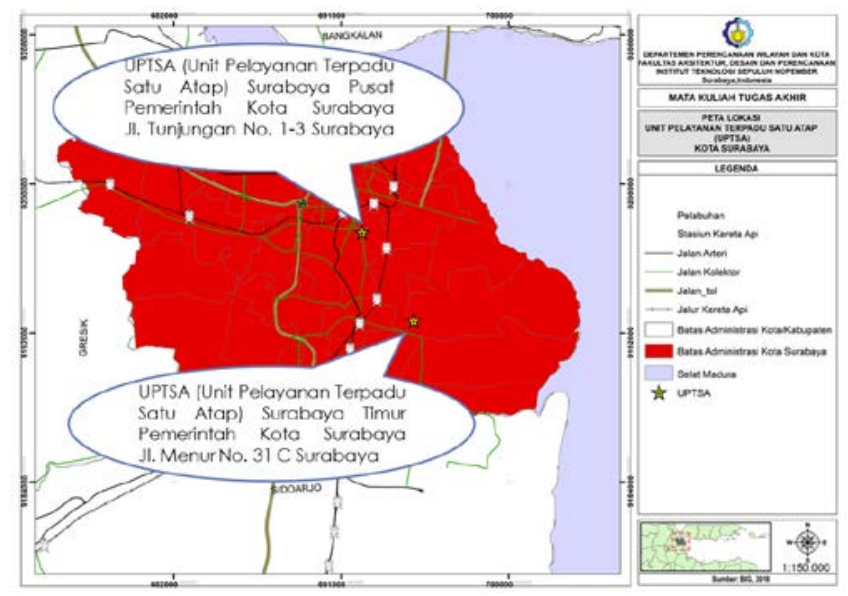

Gambar. 3. Lokasi Penelitian [5].

\section{B. Variabel Penelitian}

Variabel penelitian yang menjadi objek yang akan diteliti dalam penelitian ini didapatkan dari hasil kajian pustaka mengenai substansi-substansi yang relevan dengan sasaran penelitian. Berikut merupakan tabel variabel dari penelitian ini.

Tabel 1.

Indikator, Variabel dan Definisi Operasional Azizah \& Navastara,2019

\begin{tabular}{|c|c|c|}
\hline Indikator & Variabel & "Definisi Operasional \\
\hline Sistem & Input & $\begin{array}{l}\text { Kegiatan yang menjadi sumber sumber dari } \\
\text { tujuan kegiatan yang akan dilakukan. }\end{array}$ \\
\hline $\begin{array}{l}\text { Surabaya } \\
\text { Single }\end{array}$ & Proses & $\begin{array}{l}\text { Kegiatan pengolahan data / informasi dari } \\
\text { sumber yang didapatkan pada input }\end{array}$ \\
\hline Window & Output & $\begin{array}{l}\text { Kegiatan yang dilakukan dari hasil proses yang } \\
\text { dilakukan. }\end{array}$ \\
\hline
\end{tabular}

Input

Kegiatan yang menjadi sumber sumber dari tujuan kegiatan yang akan dilakukan.

Pelayanan Proses Kegiatan pengolahan data / informasi dari Publik sumber yang didapatkan pada input

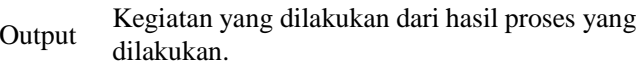

\section{Metode Analisis}

Eksplorasi permasalahan pelayanan Izin Mendirikan Bangunan di Kota Surabaya dengan akses sistem Surabaya Single Window melalui Unit Pelayanan Terpadu Satu Atap dilakukan dengan dua tahapan analisis antara lain:

\section{Identifikasi Tahapan Pelayanan Izin Mendirikan Bangunan di Kota Surabaya}

Pada tahapan ini, data tahapan pelayanan Izin Mendirikan Bangunan di Kota Surabaya yang telah didapatkan sebelumnya diklasifikasikan kedalam variabel berdasarkan definisi operasional yang telah di tentukan menggunakan analisis deskriptif kualitatif. Analisis deskriptif kualitatif dilakukan dengan cara mengumpulkan data yang dibutuhkan kemudian disusun secara sistematis, digolongkan dalam pola dan tema, dikategorisasikan dan diklasifikasikan, dihubungkan antara satu data dengan data yang lain kemudian dilakukan intepretasi untuk memahami makda data dalam situasi sosial, dan dilakukan penafsiran dari perspektif peneliti setelah memahami keseluruhan kualitas data. Selanjutnya disajikan seara deskriptf dan sistematis [6].

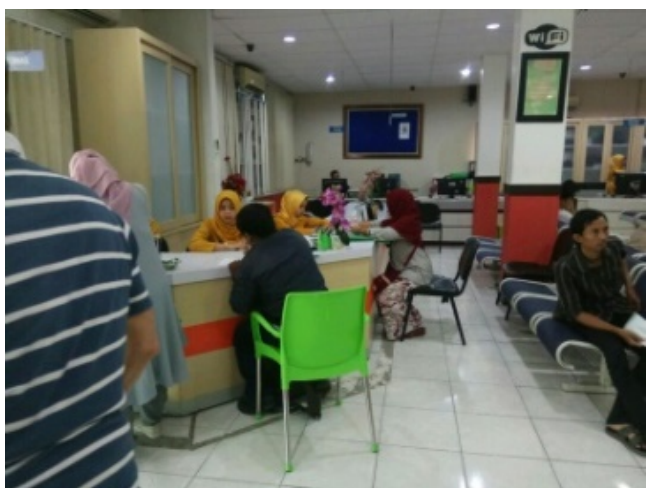

Gambar 2. Kegiatan Layanan Konsultasi IMB di UPTSA Timur [5]

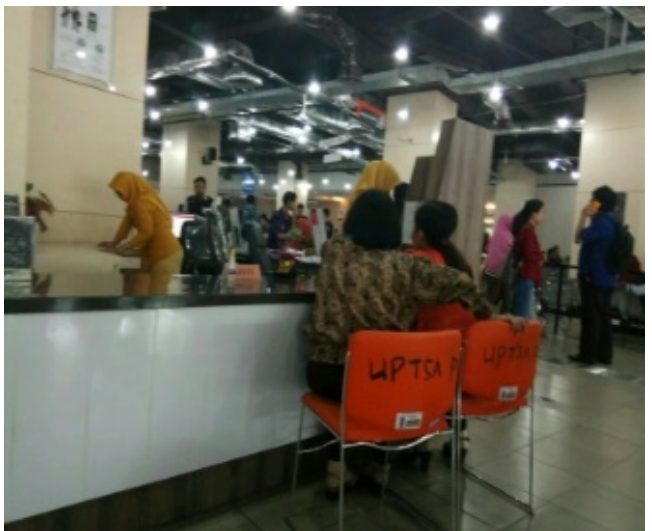

Gambar 3. Kegiatan Layanan Konsultasi IMB di UPTSA Pusat [5]

\section{E. Identifikasi Permasalahan Pelayanan Izin Mendirikan Bangunan di Kota Surabaya}

Setelah kegiatan pelayanan Izin Mendirikan Bangunan di Kota Surabaya diklasifikasikan kedalam masing - masing variabel yang telah ditentukan, eksplorasi permasalahan yang terjadi per variabel dengan kriteria kegiatan yang telah ditentukan pada analisa sebelumnya pada pemohon Izin Mendirikan Bangunan Kota Surabaya dengan akses Surabaya 
Single Window melalui Unit Pelayanan Terpadu Satu Atap (UPTSA). Langkah selanjutnya adalah melakukan analisis deskriptif. Teknik analisis data yang digunakan dalam analisis deskriptif ini adalah dengan pengumpulan data, reduksi data, penyajian data, dan penarikan kesimpulan [7].

Dari hasil tersebut dilakukan klarifikasi kepada pihak yang bertanggungjawab terhadap masing masing tahapan yakni Unit Pelayanan Terpadu Satu Atap (UPTSA) Kota Surabaya dan Dinas Cipta Karya dan Tata Ruang (DCKTR) Kota Surabaya menggunakan analisis Isi (Content Analysis). Analisis isi adalah suatu teknik sistematis yang digunakan dalam menganalisis sebuah isi pesan dan mengolah pesan atau suatu hal untuk mengobservasi dan menganalisis isi perilaku komunikasi yang terbuka dari komunikator yang dipilih [8] Sehingga didapatkan permasalahan pelayanan Izin Mendirikan Bangunan yang seimbang dari pemohon dan pelaksana Izin Mendirikan Bangunan.

\section{METODE PENELITIAN}

\section{A. Identifikasi Tahapan Pelayanan Izin Mendirikan Bangunan di Kota Surabaya}

Dalam pelaksanaan pelayanan Izin Mendirikan Bangunan terdapat tata cara penyelesaian permohonan pembuatan Izin
Mendirikan Bangunan berdasarkan Peraturan Walikota Surabaya No. 13 Tahun 2018 tentang Pedoman Teknis Pelayanan Izin Mendirikan Bangunan. Selanjutnya, pelaksanaan Izin Mendirikan Bangunan pada peraturan tersebut dan kondisi pelaksanaan pelayanan di lapangan dilakukan proses klasifikasi menjadi tahapan berdasarkan definisi operasional, penanggung jawab kegiatan, dan lokasi kegiatan berlangsung. Berikut hasil klasifikasi kegiatan pelayanan Izin Mendirikan Bangunan di Kota Surabaya..

\section{KESIMPULAN DAN SARAN}

\section{A. Analisis Kebutuhan Air}

Kebutuhan air tawar didapatkan dengan mencari selisih konsumsi air tawar dengan ketersediaan air tawar. Kebutuhan air tawar didapatkan dengan mengalikan jumlah kebutuhan air per-subjek sesuai Standar Nasional Indonesia (SNI) sedangkan ketersediaan air tawar didapatkan dari penjumlahan ketersediaan air sumur dengan produksi air PAM adapun jumlah air tawar yang perlu diproduksi oleh Desalination Production Vessel (DPV) dapat dilihat pada Tabel 1.

Tabel 2.

Tahapan Pelaksanaan Pelaksanaan Pelayanan IMB melalui UPTSA [5].

\begin{tabular}{ccc}
\hline \hline $\begin{array}{c}\text { Variabel } \\
\text { /Tahapan }\end{array}$ & $\begin{array}{c}\text { Penanggung Jawab/ } \\
\text { Lokasi Kegiatan } \\
\text { Berlangsung }\end{array}$ & Definisi \\
\hline Input & UPTSA Kota Surabaya & $\begin{array}{c}\text { Kegiatan } \\
\text { yang } \\
\text { menjadi } \\
\end{array}$ \\
& sumber \\
& sumber da \\
& tujuan \\
& kegiatan \\
& yang akan \\
& dilakukan.
\end{tabular}

Pemohon melakukan layanan konsultasi pelayanan Izin Mendirikan Bangunan di Unit Pelayanan Terpadu Satu Atap atau di Dinas Cipta Karya dan Tata Ruang Kota Surabaya

Pemohon mengajukan permohonan kepada Kepala Dinas dengan mengisi formulir permohonan secara online melalui website https://ssw.surabaya.go.id/ serta mengungggah persyaratan persyaratan yang diperlukan atau dapat dilakukan secara manual dengan mendatangi kantor Unit Pelayanan Terpadu Satu Atap dengan membawa berkas persyaratan

Petugas Unit Pelayanan Terpadu Satu Atap meneliti dokumen yang telah diupload untuk selanjutnya memberikan konfirmasi mengenai kelengkapan persyaratan yang telah diunggah(ketika kegiatan pemasukan berkas persyaratan dilakukan secara manual);

Apabila sesuai dengan hasil konfirmasi dari petugas Unit Pelayanan Terpadu Satu Atap, persyaratan telah lengkap maka pemohon dapat mencetak tanda bukti telah menggunggah berkas persyaratan secara elektronik. (Proses petugas Unit Pelayanan Terpadu Satu Atap melakukan kegiatan checklist kelengkapan persyaratan)

Untuk keperluan verifikasi dan validasi data, pemohon menyerahkan berkas persyaratan sebagai mana diatur dalam peraturan yang berlaku dilampiri tanda bukti telah mengupload berkas persyaratan ke Unit Pelayanan Terpadu Satu Atap (ketika kegiatan pemasukan berkas persyaratan dilakukan secara online);

Apabila persyaratan belum lengkap maka petugas Unit pelayanan Terpadu Satu Atap akan memberikan informasi kepada pemohon begitu pula jika berkas telah lengkap petugas Unit Pelayanan Terpadu Satu Atap wajib megirimkan ketahap selanjutnya yaitu tahap proses oleh instansi terkait

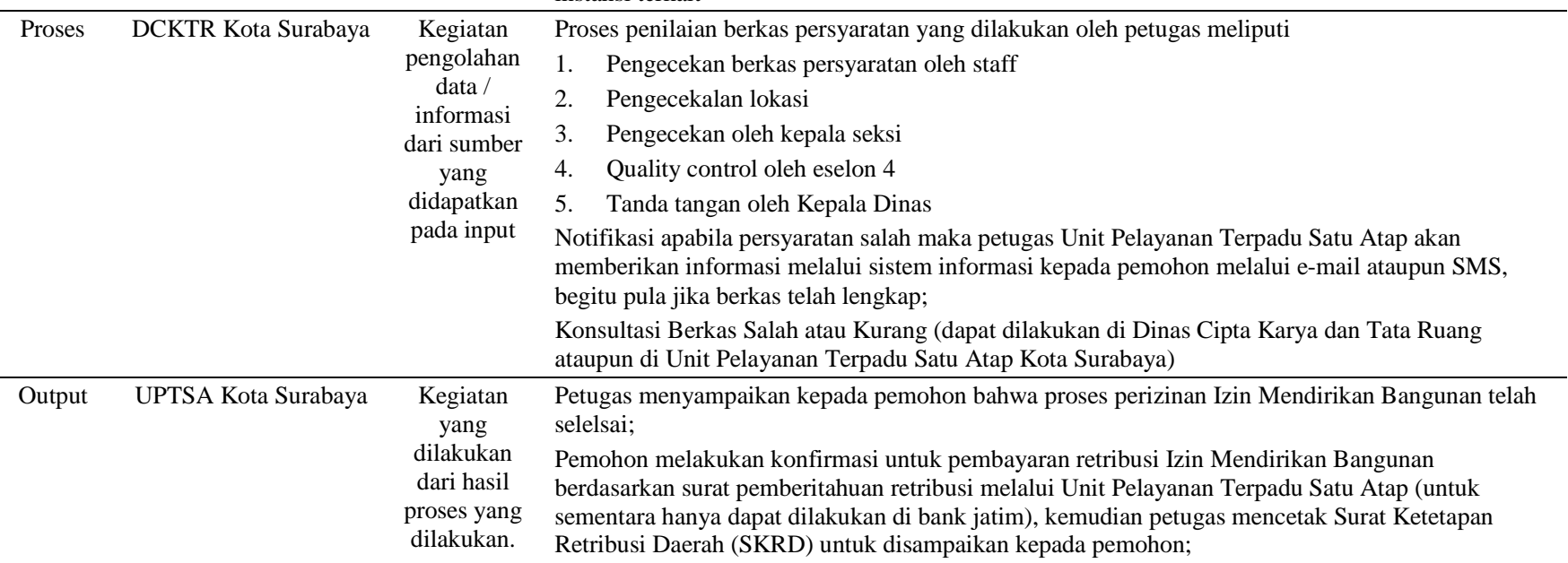


Pemohon melakukan pembayaran retribusi Izin Mendirikan Bangunan pada bank yang telah ditunjuk (semenara hanya bank jatim) dan diberikan tanda bukti pembayaran yang telah diberi paraf petugas dan stampel bank;

Bukti pembayaran retribusi untuk selanjutnya diserahkan melalui Unit Pelayanan Terpadu Satu Atap; Berdasarkan bukti pembayaran tersebut Dinas wajib menerbitkan SK Izin Mendirikan Bangunan dan menyerahkan kepada pemohon melaui petugas Unit Pelayanan Terpadu Satu Atap. Peneribitan SK Izin Mendirikan Bangunan dilakukan paling lama 1 hari kerja sejak pembayaran retribusi Izin Mendirikan Bangunan.

\section{B. Identifikasi Permasalahan Pelaksanaan Pelayanan Izin Mendirikan Bangunan di Kota Surabaya}

Berdasarkan dari hasil identifikasi tahapan pelayanan Izin Mendirikan Bangunan di Kota Surabaya, dijadikan sebagai acuan ketika menggali permasalahan pelayanan Izin Mendirikan Bangunan menggunakan kuisioner. Sampel responden dilakukan secara acak dan bertujuan (purposive sampling), dilakukan secara acak dan bertujuan diharapkan dapat mengenai seluruh lapisan pemohon Izin Mendirikan Bangunan di Kota Surabaya akan tetapi tetapi tetap fokus pada tujuan penelusuran permasalahan pelayanan. Berikut sampel responden (pemohon Izin Mendirikan Bangunan) yang didapatkan:

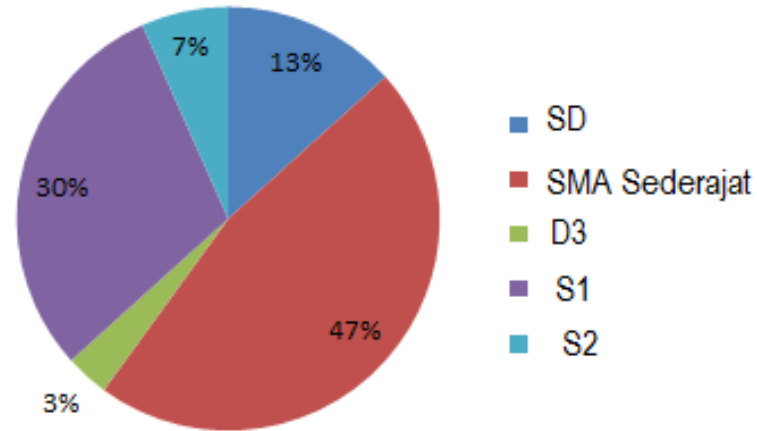

Gambar 4. Grafik Tingkat Pendidikan Sampel Pemohon Izin Mendirikan Bangunan [5].

Dari gambar grafik tersebut menunjukkan sampel memiliki tingkat pendidikan yang bervariasi, dengan presentase terbesar pada tingkat pendidikan SMA sederajat.

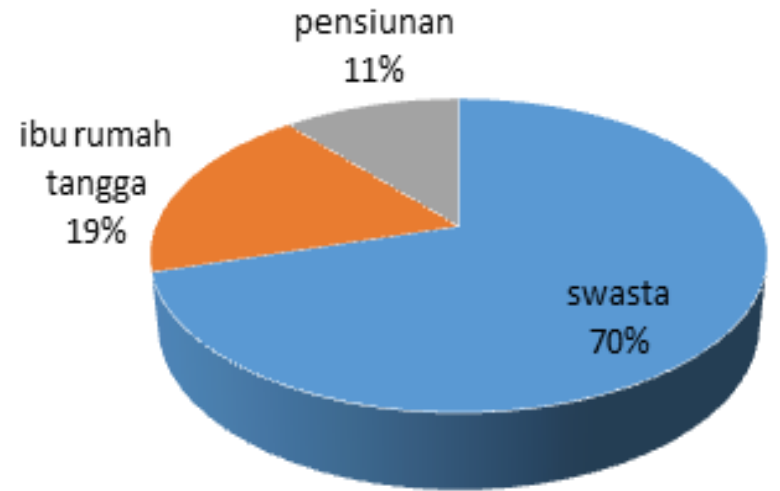

Gambar 5. Grafik Jenis Pekerjaan Sampel Pemohon Izin Mendirikan Bangunan [5].

Dari gambar grafik tersebut menunjukkan bahwa sampel pemohon Izin Mendirikan Bangunan hanya terdiri dari tiga jenis pekerjaan yakni swasta, ibu rumah tangga dan pensiunan, dengan jumlah yang mendominasi bekerja di swasta. Berdasarkan hasil kuisioner yang dilakukan pada sampel responden tersebut didapatkan permasalahan yang dirasakan oleh 30 responden selama pelayanan Izin Mendirikan Bangunan. Berikut adalah penjelasan permaslaahan yang dirasakan dalam pelayanan Izin Mendirikan Bangunan beserta klarifiikasi dari Dinas yang terkait:
1) Tahap Input

a. Tidak ada mitra Gambar Design

Dari kuisioner pertanyaan terbuka yang diberikan 8 dari 30 responden menjawab bahwa pemohon sering terkendala dalam pembuatan gambar, dimana pemohon tidak memiliki kerabat/relasi yang mampu dalam pembuatan gambar denah yang dipersyaratkan, sehingga pemohon kesulitan dalam melaksanakan mengumpulkan berkas persyaratan Izin Mendirikan Bangunan.

\section{b. Sistem Eror}

Dari kuisioner pertanyaan terbuka yang diberikan 3 dari 30 responden menjawab bahwa sering terjadi kendala eror pada sistem Surabaya Single Window seperti website tidak bisa diakses/server down, tidak bisa upload dokumen, gagal upload dokumen dan dokumen yang diupload tidak muncul.

c. Tidak adanya Petugas yang standby di dekat Meja

Komputer dan Scanner

Dari kuisioner pertanyaan terbuka yang diberikan 3 dari 30 responden menjawab bahwa tidak adanya petugas yang berjaga di dekat komputer dan scanner, sehingga ketika pemohon bingung dalam mengoperasikan baik sistem Surabaya Single Window, mengunggah ataupun melakukan scan maka pemohon harus mencari petugas terdekat terlebih dahulu.

d. Waktu Pelayanan Kurang Lama

Dari kuisioner pertanyaan terbuka yang diberikan 1 dari 30 responden mengeluhkan bahwa waktu pelayanan hanya dilakukan sampai pukul 3 sore, hal ini dirasakan kurang lama.

2) Tahap Proses

a. Notifikasi Berulang

Dari kuisioner pertanyaan terbuka yang diberikan 6 dari 30 responden menyatakan bahwa seringkali terjadi pengulangan notifikasi kekurangan data ataupun data yang salah, dan feedback yang lama. Hal ini dirasa tidak praktis karena sering bolak - balik.

3) Tahap Output

b. Waktu dan Lokasi Pembayaran Retribusi

Dari kuisioner pertanyaan terbuka yang diberikan 1 dari 30 responden mengeluhkan bahwa pembayaran retribusi terlalu cepat dan 2 dari 30 responden mengeluhkan bahwa pembayaran hanya ditujukan kepada 1 bank saja.

Selain itu, meskipun tidak disebutkan oleh pemohon Izin Mendirikan Bangunan sebagai permaslaahan, akan tetapi berdasarkan observasi yang dilakukan selama kegiatan pelayanan Izin Mendirikan Bangunan, pemanfaatan sistem Surabaya Single Window dirasa masih kurang. Pemohon lebih memilih membawa berkas persyaratan ke Unit Pelayanan Terpadu Satu Atap untuk pelaksanaan pengunggahan persyaratan dibandingkan melakukan secara mandiri.

Berdasarkan konfirmasi yang telah dilakukan dengan Dinas terkait, diketahui bahwa petugas mengakui masih terjadinya sistem eror dalam pelaksanaannya. Hal ini dikarenakan banyaknya perizinan yang dilakukan melalui sistem Surabaya Single Window. Meski demikian, Pemerintah selalu melakukan perbaikan pada sistem 
didasarkan pada jangka 1 tahun pelayanan tersebut. Selain itu, setelah dilakukan sinkronisasi ternyata ditemukan bahwa tidak semua permasalahan yang dirasakan pemohon merupakan bentuk permasalahan yang sesungguhnya, akan tetapi merupakan bentuk dari kurangnya informasi yang diterima pemohon, sehingga terjadilah kesalahpahaman khususnya terkait detail klausul persyaratan, dan tahapan pelayanan IMB serta hal hal terkait aturan pelayanan Izin Mendirikan Bangunan di Kota Surabaya melalui Unit Pelayanan Terpadu Satu Atap.

Tabel 3.

Klarifikasi Permaslaahan Pelaksanaan Pelayanan IMB melalui [5]:

\begin{tabular}{ccc}
\hline \hline Tema & Permasalahan & Responden \\
\hline & & \\
\hline Sumber & Tidak adanya Mitra & Kepala UPTSA \\
Daya & Gambar Design & Surabaya Pusat \\
Manusia & &
\end{tabular}

Tahap Input

Rumusan

Manusia

Konsultasi gambar design dapat dilakukan pada loket konsultasi teknis. Petugas akan membantu dalam membuatkan gambar design pada pemohon dengan kriteria rumah tinggal sederhana 2 lantai dan luas kurang dari $500 \mathrm{~m}^{2}$. Selain rumah tinggal sederhana Pembuatannya dapat dibantu oleh pihak ketiga ataupun membuat sendiri. Pemerintah Kota Surabaya tidak melakukan kerjasama terkait jasa pembuatan gambar design untuk mengurangi kecurangan dan memberikan kesempatan yang sama pada seluruh penyedia jasa konsultasi.

Staff Sekretariat Bantuan pembuatan gambar design hanya khusus rumah tinggal 2 lantai sederhana. Selain

Dinas Cipta jenis rumah tinggal sederhana, pemohon diperkenankan menggunakan jasa Konsultan.

Karya dan Tata Pemohon juga dapat menemukan jasa konsultan diantara pemohon yang sedang Ruang mengajukan proses perizinan. Petugas tidak diperbolehkan melakukan penunjukan kepada konsultan tertentu.

Tidak ada Petugas Kepala UPTSA Standby di dekat Meja Surabaya Pusat Komputer dan Scanner

Adanya Komputer dan Scanner yang di sediakan di Unit Pelayanan Terpadu Satu Atap dimaksudkan sebagai loket mandiri, dimana masyarakat secara mandiri dapat melakukan kegiatan input persyaratan secara mandiri (sendiri) dengan fasilitas yang disediakan berserta instruksi (lembar tahapan pelaksanaan) yang telah diberikan pada masing masing komputer dan scanner yang ada, dengan harapan masyarakat lebih memahami dan menyebarkan pemahaman pelaksanaan pelayanan Izin Mendirikan Bangunan pada orang disekitarnya.

Staff Sekretariat Sejauh ini telah dilakukan sosialisasi guna mencerdaskan masyarakat terkait sistem Dinas Cipta Surabaya Single Window diantaranya :Sosialisasi ketika diadakannya acara besar di Karya dan Tata Surabaya seperti pada acara Pantura, Ulang tahun Kota Surabaya dan juga melalui video Ruang di youtube.

$\begin{array}{ll}\text { Sistem } \quad \text { Sistem Eror } & \begin{array}{l}\text { Kepala UPTSA } \\ \text { Surabaya Pusat }\end{array}\end{array}$
Pemerintah akan selalu melakukan perbaikan pada sistem, dengan melihat dalam jangka waktu 1 tahun apakah sistem Surabaya Single Window memberikan presentase pelayanan yang lebih besar. Dikatakan berhasil apabila pelayanan lebih dari $70 \%$ dari jumlah pelayanan itu sendiri .

\begin{tabular}{ccc}
\cline { 2 - 3 } Layanan & Waktu Pelayanan & Kepala UPTSA \\
Kurang Lama & Surabaya Pusat
\end{tabular}
Waktu pelayanan hari senin sampai jumat pukul 7.30 WIB - 15.00 WIB. Hari sabtu pukul $9.00 \mathrm{WIB}-14.00$.

Setiap bulan pada minggu 3 terdapat layanan pukul 09.00 sampai jam 12.00

Pelayanan ditutup pukul 15.00 WIB dimaksudkan bahwa pengambilan antrian hanya samapai pada waktu tersebut. Apabila setelah jam tersebut masih ada sisa pemohon maka akan terus dilakukan pelayanan hingga pemohon dengan No. antrian sebelum pukul 15.00 selesai.

\section{Tahap Proses}

\begin{tabular}{ccc}
\hline Notifikasi & Notifikasi Berulang & Staff Sekretariat \\
& Dinas Cipta \\
& Karya dan Tata \\
& Ruang \\
\cline { 2 - 2 } & Kepala UPTSA \\
& Surabaya Pusat
\end{tabular}

Data dari Unit Pelayanan Terpadu Satu Atap di cek oleh staff $\rightarrow$ dilakukan survei oleh surveyor $\rightarrow$ di cek oleh kepala seksi (eselon 3) $\rightarrow$ quality control oleh eselon $4 \rightarrow$ ditanda tangani oleh Kepala Dinas.

Unit Pelayanan Terpadu Satu Atap memiliki prosedur standar administrasi yang menyatakan bahwa apabila pemohon dirasa sudah memenuhi checklist berkas persyaratan maka Unit Pelayanan Terpadu Satu Atap wajib meloloskan dokumen tersebut kepada Dinas yang melakukan proses (dalam hal Izin Mendirikan Bangunan adalah Dinas Cipta Karya dan Tata Ruang).

Kekurangan berkas secara berulang bisa jadi dikarenakan isi dari klausul teknis yang terdapat pada persyaratan yang dimaksud memiliki keterkaitan dengan dokumen yang diminta.

\section{Tahap Output}

$\begin{array}{ccc}\text { Layanan } & \begin{array}{c}\text { Waktu dan Lokasi } \\ \text { Pembayaran Retribusi }\end{array} & \begin{array}{l}\text { Kepala UPTSA } \\ \text { Surabaya Pusat }\end{array}\end{array}$

Pembayaran retribusi Izin Mendirikan Bangunan dilakukan 1x selama tidak ada perubahan pada bangunan. Pembayaran dilakukan maksimal 7 hari setelah pemohon menerima pemberitahuan mengenai pembayaran retribusi. Apabila dilakukan lebih dari 7 hari maka pemohon diwajibkan mengulang pelayanan Izin Mendirikan Bangunan dari awal. Proses ulang ini tidak akan memerlukan waktu yang lama apabila dilakukan dalam jangka waktu kurang dari 1 tahun dan tidak ada perubahan. Adanya perubahan dikarenakan indeks yang diatur oleh perwali.

Pemerintah saat ini sedang dalam proses melakukan kerjasama dengan bank - bank pemerintah seperti BNI, BRI dan Mandiri, sehingga diharapkan kedepannya pemohon dapat membayar lewat berbagai bank. Dinas - dinas terkait sedang mengusahakan membuat akun rekening bank - bank tersebut supaya ikut dalam memudahkan pembayaran. Setelah melakukan pembayaran pembayaran, petugas langsung melakukan kegiatan cetak SK Izin Mendirikan Bangunan. Pemohon dapat menunggu sekitar setengah jam untuk proses pencetakannya. 


\section{KESIMPULAN}

Terdapat permasalahan yang dikeluhkan oleh pemohon selama pelaksanaan pelayanan Izin Mendirikan Bangunan di Kota Surabaya terkait Sumber Daya Manusia, Sistem, Layanan dan Notifikasi.

Pemanfaatan sistem Surabaya Single Window dirasa masih kurang. Pemohon lebih memilih membawa berkas persyaratan ke Unit Pelayanan Terpadu Satu Atap untuk pelaksanaan pengunggahan persyaratan dibandingkan melakukan secara mandiri.

Setelah dilakukan klarifikasi pada pihak yang bertanggung jawab terhadap pelaksanaan masing masing tahapan didapatkan bahwa masyarakat Kota Surabaya tidak sepenuhnya memahami pelayanan Izin Mendirikan Bangunan di Kota Surabaya khususnya terkait detail pada klausul persyaratan, dan tahapan pelaksanaannya. Sehingga terjadi kesalahpahaman, dimana pemohon Izin Mendirikan Bangunan menyatakan bahwa keluhan tersebut sebagai permasalahan, sedangkan menurut petugas yang bertanggungjawab, hal tersebut merupakan bagian dari prosedur dan ketentuan yang ditetapkan.

\section{DAFTAR PUSTAKA}

[1] D. Widyaningsih, "Kota Surabaya Menuju Smart City,” Universitas Gajah Mada, 2013.

[2] I. Nurida, Manajemen Administrasi Perkantoran. Yogyakarta: Penerbit Kanisius, 2008.

[3] E. A. S. Sapoetro, "Surabaya Single Window, Surabaya," 2017.

[4] Pemerintah Kota Surabaya, Profil Kota Surabaya 2016. Surabaya: Dinas Komunikasi dan Informatika Kota Surabaya, 2016.

[5] I. Azizah and A. M. Navastara, "Implementasi Pelayanan Izin Mendirikan Bangunan di Kota Surabaya melalui Unit Pelayanan Terpadu Satu Atap (UPTSA),” Intitut Teknologi Sepuluh Nopember, 2019

[6] I. M. Diatha, Metodologi Penelitian Hukum Normatif dalam Justifikasi Teori Hukum. Jakarta: Prenada Media Grup, 2017.

[7] M. B. Miles and A. M. Huberman, Qualitative Data Analysis. Thousand Oaks: Sage, 1994

[8] R. Kriyanto, Teknik Praktis Riset Komunikasi. Jakarta: Kencana Prenada Media Grup, 2016. 